\title{
KÜRESEL KAMUSAL MAL OLARAK FINANSAL İSTİKRAR KAVRAMI
}

\section{Yasemin YILDIRIM *}

\section{Özet:}

Dünyanın pek çok farklı bölgelerinin karşılıklı olarak birbirini etkilemesiyle oluşan küreselleşme olgusu özellikle 1980 sonrasında büyük bir ivme kazanmıştır. Uluslararası bağlamda ülkelerin finans sistemleri birbirine entegre olduğu için ve kamusal mal özelliklerini taşıdığı için, finansal istikrar bir küresel kamusal mal olarak kabul edilebilir. Dolayısıyla herhangi bir ülkede yaşanan finansal istikrarsızlık durumunda ise bunun küresel bir boyuta ulaşabileceği şüphesizdir. Bu kapsamda çalışmada küreselleşme ve kamusal mal kavramlarından yola çıkılarak finansal istikrar kavramı ve finansal istikrarın sağlanmasına yönelik ulusal ve uluslararası kuruluşlar ele alınmıştır. Çalışmada, bu finansal kuruluşların öneminin yanında küresel finansal istikrarın sağlanmasının her bir ülkenin kendi mali durumunu disipline etmesine de bağlı olduğu sonucuna varılmaktadır.

Anahtar Kelimeler: Küreselleşme, Küresel kamusal mallar, Finansal istikrar.

\section{Concept of Financial Stability as Global Public Goods}

\begin{abstract}
Absract:
The cases of globalization created by mutual interaction of many different parts of the world has gained momentum especially after 1980. Financial stability can be regarded as a global public good because the financial systems of countries in the international context are integrated with one another and carry the characteristics of public goods. Therefore, in the case of financial instability in any country, it is certain that it will reach a global dimension. In this
\end{abstract}

* Öğr. Gör., Ordu Üniversitesi, Sosyal Bilimler MYO., yaseminyenigun@ odu.edu.tr 
context, the concept of financial stability and the national and international institutions aiming at providing financial stability have been discussed through the concept of globalization and public goods. It is concluded in the study that the provision of global financial stability alongside those of these financial institutions is also dependent on each country disciplining its own financial position.

Keywords: Globalization, Global public goods, Financial stability.

\section{Giriş}

Günümüzde küresel düzeyde ilişkilerin artması sosyal, ekonomik ve kültürel engelleri ortadan kaldırarak yeni fırsatlar ortaya çıkarırken bir yandan da bölgesel veya ulusal düzeydeki sorunların küresel hale gelerek etkilerinin daha geniş çapta hissedilmesine neden olmaktadır. Özellikle de çevre kirliliği, terör, küresel ısınma, finansal istikrarsızlık gibi negatif dışsallığı olan sorunların küresel ölçekte ele alınması gerekir. Ekonominin de sosyal gelişmelerden fazlasıyla etkilendiği varsayımı da göz önüne alındığında finansal istikrarın sağlanması ve korunması da her zaman kolay olmamaktadır. Ayrıca kamusal malların özellikleri olan tüketimde rekabetsizlik ve dışlanamama özellikleri finansal istikrar için de geçerlidir. Bu yönüyle kamusal nitelik taşıyan finansal istikrar, ülkeler arası ticaretin serbestleşmesiyle tek bir ülkenin hedefi olmaktan çıkmış, küresel düzeyde ele alınmaya başlanmıştır. İstikrarın yokluğu ya da eksikliğiyle oluşan küresel finansal istikrarsızlığa uluslararası çözümler getirilmiştir.

Mishkin (1992), De Bandt ve Hartmann (2000), Issing (2003) gibi yazarlar finansal istikrarsızlığın yalnızca finansal kurumların mali sorunlarından kaynaklanabileceğini ileri sürmüşlerdir. Ancak finansal istikrarsızlı̆̆ın sadece finansal kurum merkezli olduğunu söylemek Allen ve Wood'a göre ise çok dar bir kapsamdır. Çünkü hükümetler, ekonomik bozulmayı önlemek için acil maddi yardımda bulunurlar ve bu yardımın sağlanmasına ilişkin maliyetlerin ve faydaların analizi, yardım alan kişinin finansal bir kurum olmasına bakılmaksızın aynıdır (Allen \& Wood, 2006: 157). 
Küreselleşmenin serbest rekabet ortamını hareketlendirici etkisiyle getirilen pek çok finansal yenilik, borçlanma olanaklarını artırmış ve finansal kırılganlıkları ortaya çıkarmıştır. Artan borçlanma eğilimleri ve spekülasyonlar finansal kriz öncesinde varlık fiyatlarını artırmış, artan fiyatların etkisiyle oluşan finansal kriz sürecinde ise varlık fiyatları hızla düşerek krizin derinleşmesine ve borç deflasyonuna yol açmıştır. Borç deflasyonu kavramı ilk olarak Fisher (1933) tarafından Büyük Buhran’ın derinliği ve uzunluğuna bir açıklama getirmek için oluşturulmuş, Minsky (1982) ve Bernanke (1983) tarafindan geliştirilmiştir (Ulusoy, Karakurt \& Ela, 2015: 2).

Literatürde finansal istikrarsızlığın açıklanmasına ilişkin farklı yaklaşımlar mevcuttur. Açıklamalardan bazıları istikrarsızlığı sistem içerisinde tanımlanmış piyasalar ile kurumların içsel yapısına, bazıları parasal şoklara, bazıları da bilgi eksikliğine dayandırmaktadır. Örneğin Bossone ve Promisel (1998) finansal kurumlardaki yetersiz risk yönetimi ile yüksek şirket borçluluklarını istikrarsızlığın iki büyük kaynağı olarak gösterir (Bossone \& Promisel, 1998: 9). Minsky’e göre kapitalist sistem genel olarak istikrarsız bir sistem olup, bu durum sistemin kendi içsel mekanizmalarından kaynaklanmaktadır. Sisteme dışarıdan müdahale edilmese bile sistem istikrarsızlık çıkarma potansiyeline sahiptir. Diğer bir ifadeyle, istikrar kapitalist bir ekonomide istikrarsızlığa neden olmaktadır. İstikrarlı bir kurumsal yapıda finansal yatırımcılara kar firsatlarının açık olması, karları maksimize etmek için finansal aracıların finansal yenilikler yapması ve para otoritelerinin yasal ve yönetsel müdahaleleri, finansal sistemin sağlam bir yapıdan kırılgan bir yapıya geçişine neden olmaktadır. Mishkin'e göre ise finansal istikrarsızlık, finansal sisteme yönelen şokların bilgi akışına engel olduğu bir durumda fonların verimli yatırım firsatlarına yönlendirilememesidir (Korkmaz \& Yamak, 2015: 52-54).

Finansal istikrarın küresel kamusal niteliklerini taşıdığını gösteren bu çalışmada, konuya daha teorik çerçevede değinilerek, bu alanda sayıca az olan diğer çalışmaların bir tamamlayıcısı olması amaçlanmıştır. Bu amaçla ilk olarak yeni küresel kamusal mallar ayrımında yerini alan finansal istikrar ve istikrarsılılı̆ın gelişimi ele 
alınacak, ardından küresel finansal istikrarın sağlanmasında ulusal ve uluslararası kurumlar açıklanmaya çalışılacaktır.

\section{Küreselleşme ve Küresel Kamusal Mal Kavramları}

\subsection{Küreselleșme Kavramı}

Küreselleşmenin üç evreden geçerek günümüzdeki halini aldığı söylenebilir. Bu evrelerden ilki 19. yüzyılın sonlarından 1914'lere kadar olan dönem, ikincisi 1914'lerden 1945-50'lere kadar olan dönem ve üçüncüsü ise 1945-50 sonrası dönemdir. 19. yüzyılın sonlarından 1914'lere kadar geçen dönemde, küreselleşmenin, özellikle iktisadi anlamda, oldukça ileri bir seviyede olduğu görülmektedir. Bu dönemde, uluslararası ticaretin önündeki engel ve tarifeler yok denecek seviyelere gerilemiş, küresel piyasaların entegrasyonu derinleşmiş, ulaşım maliyetleri ve uluslararası alanda kişilerin serbest dolaşımı önündeki kısıtlamalar en düşük seviyelere inmiştir. 1914'lerden 1945-50'lere kadar geçen süren içerisinde ise bu durum tersine dönmüştür. I. Dünya Savaş1 ile başlayan, büyük bunalım ile devam eden ve II. Dünya Savaşı'nın bitmesi ile sona eren bu dönem, küreselleşme dinamiklerinin ve global entegrasyon akımlarının ciddi bir biçimde sekteye uğradığı bir dönemdir. Siyasi anlamda aşırı-milliyetçilik, iktisadi anlamda korumacılık ve kendi kendine yeterlilik türündeki eğilimler bu dönemin tipik özellikleridir. 1945-50 sonrası dönemde ve özellikle 1980 sonrasında ise küreselleşme büyük bir ivme kazanarak benzeri görülmemiş bir seviyeye ulaşmıştır. Küreselleşmenin bu denli artmasında çeşitli nedenler vardır. Ekonomik anlamda, uluslararası ticaret hacmi ve uluslararası sermaye akımlarının hızı eşi görülmemiş seviyelere erişmiş, küresel üretim süreçleri büyük bir dönüşüm yaşamıştır. Son olarak ve özellikle 1980 sonrasında, küreselleşmenin çevresel, demografik ve kültürel boyutları da kendini göstermiştir.

$\mathrm{Bu}$ açıklamalar doğrultusunda küreselleşme, en basit anlamda, yerkürenin farklı bölgelerinde yaşayan insan, toplum ve devletlerarasındaki iletişim ve etkileşim derecesinin "karşılıklı bağımlılık" kavramı çerçevesinde giderek artması olarak ta- 
nımlanabilir (Bayar, 2008: 25). Das'a göre küreselleşme, kıtalararası mesafeleri kapsayan, bunları ekonomik, sosyal, kültürel ve bilgilendirici olarak birbirine yakınlaştıran bir ilişki ağıdır (Das, 2010: 66).

\subsection{Küresel Kamusal Mal Kavramı}

Toplumsal açıdan önem taşıyan kamusal mallar ve hizmetler, fiyatlandırılamazlar ve bu nedenle de pazarlanamazlar. Finansmanı kamu gelirleriyle sağlanan kamusal mal ve hizmetler aynı anda tüm topluma sunulduğundan bu mal ve hizmetlerin kişi ve gruplar için bölünmesi mümkün değildir. Bu mal ve hizmetlerin kimler tarafindan talep göreceği ve kimler için fayda sağlayıp sağlamayacağı belirsizdir. Toplumsal ihtiyaçları karşılamaya yönelik, faydaları toplum bireyleri arasında bölünemeyen ve faydasından o ülke içindeki hiç kimsenin yoksun bırakılamadığı ve ilgili kararların siyasi süreç içerisinde verildiği mal ve hizmetlerdir (Akdoğan, 2006: 41).

Samuelson ve Musgrave kamusal mal tanımını yaparken malların sahip oldukları özellikleri esas almışlardır. Bu özellikler, malın tüketiminde bireyler arasında bir rekabetin olup olmaması, malın faydasından ilave kullanıcının dışlanıp dışlanamaması, malın tüketiminde üçüncü kişilere yayılan fakat fiyatlandırılamayan faydaların (dışsallıkların) varlığı olarak sıralanabilir (Uğurlu, 2010: 20).

Küresel kamusal mallar kavramı, ilk kez Birleşmiş Milletler Kalkınma Programı (UNDP) tarafından 1999 yılında hazırlanan "Global Public Goods: International Cooperation in the 21.Century", adlı çalışma ile gündeme gelmiştir. Dolayısıyla, küresel kamusal mallar kavramının tanımlanmasında öncelikle ele alınması gereken tanım, adı geçen çalışmadaki küresel kamusal mallar tanımıdır. Buna göre, faydası ülkeler, insanlar ve nesiller (bugünkü ve gelecekteki) açısından büyük ölçüde evrensel olan mallara küresel kamusal mallar adı verilmektedir (Yalçın, 2009: 290). Bu tanımda küresel kamusal malların iki temel özelliği öne çıkmaktadır. Birincisi, küresel kamusal malların tüketiminde rekabet yoktur ve yine tüketimden dışlanma söz konusu değildir. İkinci özelliği ise, bu malların faydalarının tüm dünya ülkelerine 
yayılmasıdır. Bu mülkiyet, insanlığın bir bütün olarak küresel kamusal malların yararlanıcısı olmasını sağlar (Kaul, Grunberg \& Stern, 1999: 3).

Küresel kamusal malların yaygın olarak kullanılan bir başka tanımı ise Dünya Bankası tarafından yapılmıştır. Bu tanıma göre küresel kamusal mallar, kalkınma ve yoksulluğun azaltılması için önemli olan ve yeterli miktarda üretimi yalnızca gelişmiş ve gelişmekte olan ülkelerin işbirliği ve toplu hareketleriyle mümkün olan, büyük ölçüde sınır ötesi dışsallıklara sahip mallar, kaynaklar, hizmetler ve politika rejimleri sistemleridir (World Bank, 2000: 2). Bu tanımda, Dünya Bankası, küresel kamusal malların yaydıkları pozitif dışsallıklar ve sunumları için uluslararası işbirliğine ihtiyaç duyulması gibi özelliklerini öne çıkarmıştır.

Öte yandan ülkeler kendi ulusal çıkarları için uğraş verirken dolaylı olarak küresel kamusal malların sağlanmasına da yardımcı olmaktadır. Ülkelerin finansal sistemlerini daha güvenli hale getirmeleri, araştırma ve geliştirme yatırımlarını artırmaları, sera gazı emisyonlarının azaltılması ve kamu sağlığının iyileştirilmesi gibi faaliyetler dolaylı olarak diğer ülkelere de fayda sağlayacaktır. Dolayısıyla ulusal kamusal mallar küresel bilgi üretme kapasitesini arttırır ve bu nedenle, küresel kamu yararının tamamlayıcısı olduğu söylenebilir (Morrissey, Velde \& Hewitt, 2002: 13).

\section{Küreselleşmenin Ekonomik Boyutu}

\subsection{Geleneksel ve Yeni Küresel Kamusal Mallar}

Önemlerini hala koruyan geleneksel küresel kamusal mallar atmosfer, ozon tabakası, açık denizler gibi doğal ortak mallar olabileceği gibi, açık denizlerden geçme gibi ulusların serbest girişimi ve 19-20. yüzyılda yoğunlaşan uluslararası ekonomik aktiviteyi çoğaltma ile ortaya çıkan gemicilik, sivil havacılık, telekomünikasyon ve posta hizmetlerinin yaygınlaştırılması anlaşmaları da olabilir. Bununla birlikte, küreselleşme ile birlikte yeni tür küresel kamusal mallar ortaya çıkmıştır. Temiz hava, sağlık, finansal istikrar, piyasa etkinliği ya da bilgi yönetimi gibi konularla ilgili olan bu yeni tür mallar, küreselleşme ile birlikte sınırların ortadan kalkması ve politika yakınsaması ile ortaya çıkar. Çünkü küreselleşme ile birlikte ulusal kamu 
politikalarının uyumlaştırılması problemleri öne çıkmaya başlamıştır. Bu konulardaki sorunlar bulaşma etkisi ile kısa sürede tüm ülkelerin ortak sorunu haline gelmektedir. Küreselleşme, ilgili konularda ülkelerin tek başına uygulayacağı politikaları yetersiz kılmaktadır. Dolayısı ile bu mallar artık küresel kamusal mal niteliğindedir. Bunların ortaya çıkmasının arkasında birkaç faktör önemli rol oynar. Bunlardan ilki ülkelerin artan dışa açıklık derecesidir. Dışa açıklık küresel kötülerinin yay1lımını kolaylaştırmaktadır. İkincisi, artan küresel sistemden kaynaklı risklerdir. Bu riskler, uluslararası finansal piyasalarda volatilite riskleri (belirli bir ürünün belirli bir zaman içerisinde fiyatında yaşanan oynaklığı), küresel iklim değişimi riski ya da artan küresel eşitsizliğin doğurduğu politik riskler gibi riskleridir. Üçüncüsü ise, devlet dış1 aktörlerin artan gücüdür. Başta çokuluslu işletmeler olmak üzere, özel sektör ve sivil toplum kuruluşlarının gücü gittikçe artmaktadır (Akdemir \& Şahin, 2006: 6).

\subsection{Küresel Kamusal Mal Olarak Finansal İstikrar ve Finansal İstik- rarsızlık}

Finansal istikrarın sağlanması ve sürdürülmesinin bir politika hedefi olarak kabul edilmesiyle, bu alanda yapılan çalışmaların sayısı hız kazanmıştır. Ancak finansal istikrarın kesin tanımına ilişkin bir görüş birliği olmasa da Schinasi’ye göre finansal istikrar; bir ekonominin performansını kolaylaştırabilen ve içsel olarak veya önemli olumsuz ve öngörülemeyen olayların bir sonucu olarak ortaya çıkan mali dengesizliklerin giderilmesinde finansal sistemin bir istikrar içinde olmasıdır (Schnasi, 2004: 8). Finansal istikrar kavramına yönelik olarak Borio ve Drehmann (2009) tarafından yapılan bir diğer tanımda finansal istikrar kavramı finansal istikrarsızlığın tersi olarak görülmekte; finansal istikrarsızlık da normal boyuttaki şoklar karşısında finansal zorluk ya da olumsuzlukların ortaya çıkması için yeterli olan koşullar bütünü olarak ifade edilmiştir (Borio \& Drehmann, 2009: 4). Şen ve Altay’a (2010) göre ise finansal istikrar ekonomik büyüme ve makroekonomik istikrar için bir önkoşuldur. Finansal istikrar, finansal sistemin kaynakları etkin bölüştürme, riskleri bertaraf ederek firsata dönüştürme ve menkul kıymet işlem ve ödemelerini sağlam bir şekilde yerine getirme yeteneğini ifade eder (Şen \& Altay, 2009: 165). 
Finansal hizmetlerden yararlananlar diğerlerini de bu hizmetlerden yararlanmaktan mahrum bırakmamaktadır. Ayrıca finansal hizmetlerin de tüketiminde rekabetin olmaması finansal istikrarı kamusal bir mal kategorisine sokmaktadır. Üstelik faydası ülke dışına taştığı için ya da finansal istikrarsızlık diğer ülkeler için de potansiyel bir tehlike olduğu için finansal istikrar küresel kamusal maldır. Bu bağlamda Crockeet (1997) de finansal istikrarı kamu malı olarak tanımlamaktadır. Çünkü finansal istikrarın tüketicileri (hizmeti kullananlar) diğerlerini istikrardan faydalanma ihtimalinden yoksun bırakamamakta ve istikrardan tüm katılımcılar eş zamanlı olarak faydalanabilmektedirler (Crockeet, 1997: 14).

Küresel finans sisteminde özellikle de 1980'li yılların başından itibaren ortaya çıkan çağdaş küreselleşme sürecinin önceki süreçlerden farklı özellikler taşıdığını söylenebilir. Bu özelliklerin başında 1980'li yıllardan sonra pek çok ülkenin küreselleşmeyi geniş ölçüde destekleyen liberal makroekonomik politika rejimlerini geliştirmeye başlaması ve piyasa mekanizmasına dayalı bir ekonomik yapı oluşturmaya yönelik reformlar uygulamaya koyması söz konusudur. Bu anlamda ticaret engellerinin azaltılması, sermaye akımlarının serbestleştirilmesi, çok taraflı ticaret, GATT (Tarife ve Ticaret Genel Anlaşması) ve WTO çerçevesinin uygulanması, navlun ve liman ücretlerinde istikrarlı bir düşüş gibi uygulamalar getirilmiştir (Das, 2010: 70). Burada GATT, II. Dünya Savaşı'nın sona ermesinin hemen ardından kurulan ekonomik iyileşmeyi artırmak için uygulanan, dünyadaki ilk çok taraflı serbest ticaret anlaşmasıydı. GATT 30 Haziran 1948'den 1 Ocak 1995'e kadar yürürlükte kalmıştır. WTO (Dünya Ticaret Örgütü) ise GATT'ın yerine kurulan, 1 Ocak 1995 tarihinde çok taraflı ve çoklu ticaret anlaşmalarının uygulanmasına yönelik faaliyetlerin düzenlenmesini sağlayan, çok taraflı ticaret sisteminin yasal ve kurumsal temeli olan anlaşmadır. Bilgi ve iletişim teknolojilerinin gelişmesiyle birlikte ulaştırma maliyetlerinin azalmasıyla da ticaret hacmi daha fazla uluslararası hale gelmiştir (Das, 2010: 69). Dolayısıyla sermaye hareketlerinin bu denli artması, bir ülkede yaşanan mali istikrarsızlı̆̆ın etkisinin sadece o ülkede kalmamasına ve diğer ülkelerde de görülmesine neden olmaktadır. 
Aşağıdaki şekilde Mishkin sanayileşmiş ülkelerde finansal krizlerin ortaya çıkışını özetlemiştir (Mishkin, 1997: 74). ABD'deki finansal krizlerin çoğu, faiz oranlarında belirgin bir yükseliş, bankaların bilançolarında bozulmalar, bir borsa krizi ve belli başlı finansal veya finansal olmayan firmaların başarısızlığından kaynaklanan belirsizliklerin artmasıyla başlamıştır. Bu ise ters seçim ve ahlaki tehlikeyi artırarak, borç verenlerin borç verme konusunda çekimser davranmasına ve yatırımların ve toplam ekonomik faaliyetlerin düşmesine neden olmaktadır (Mishkin, 1991: 73).

Şekil 1: Sanayileşmiş ülkelerde finansal istikrarsızlı̆̆ın gelişimi

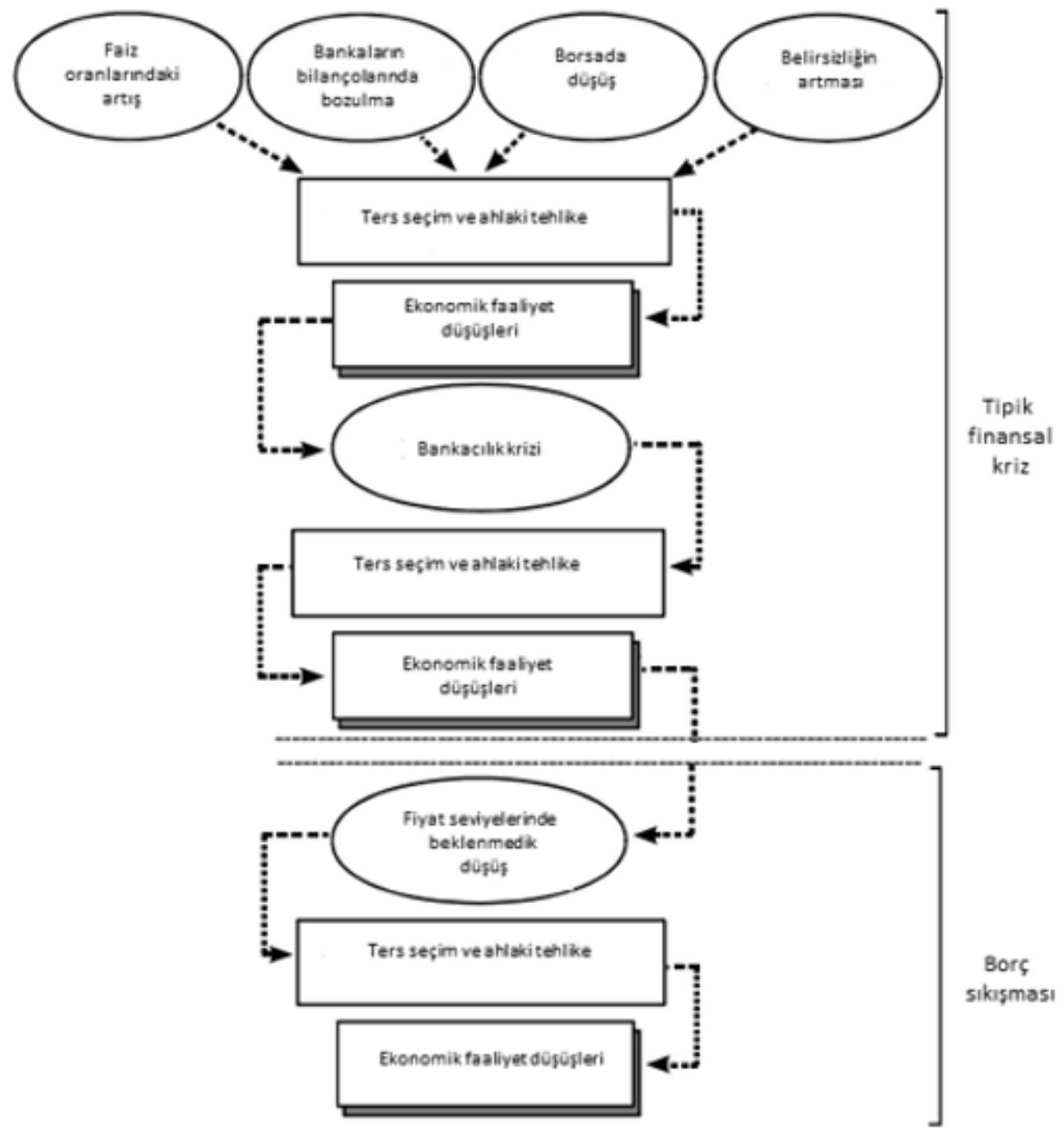


Büyük bir finansal kurumun ve piyasanın çökmesi diğer finansal kurum ve piyasalardaki ajanların da refahını etkileyen bir etkiye sahiptir. Bu etki kartopu gibi artarak büyüyen bir yatırımcı paniğine dönüşerek tüm sistemi tehdit edebilecek bir potansiyele sahiptir. Bu yüzden de düzenlemelerle oluşturulan finansal sistem güvenlik ağı dışsallıkların olumsuz etkilerini minimize edecek şekilde tasarlanmalıdır. $\mathrm{Bu}$ anlamda bir kamu malı olarak düşünülebilecek finansal güvenlik sistemiyle yaratılan güven ve istikrar ortamından tüm finansal ve reel ajanlar faydalanmış olacaklardır (Yay, Gürkan Yay \& Y1lmaz, 2001: 63). Ancak en önemli piyasa başarısızlıklarından biri olan dışsallığın etkisiyle sistemin işleyişinde aksamalar meydana gelir. Küresel finans sisteminin olumsuz işleyişinde etkili olan belli başlı fay hatlarından biri küresel dengesizliklerdir. Öyle ki bazı ülkeler cari işlemler fazlası verirken bazılarının da cari açık vermesi küresel ekonomide problemlere yol açmıştır. Bu dengesizlikler sermaye akışlarının yanlış yön izlemesine, diğer bir deyişle gelişmekte olan ülkelerden gelişmiş ülkelere akmasına sebep olmaktadır. Söz konusu akışlar yatırımlara para sağlamak yerine $\mathrm{ABD}$ gibi gelişmiş ülkelerin tüketim ve bütçe açığını finanse etmektedir. Küresel krizlere bir diğer etkisi olan unsur ise 2000'li yıllarda yöneticilerin kötü yatırımlar yapsalar bile büyük ölçekli kurumlar olmaları nedeniyle kendilerine zarar gelmeyip destekleneceklerine inanmalarından dolayı aşırı risk almaktan çekinmemeleridir. Ayrıca "denetlenmeyen ve gözetlenmeyen, düzenli bankacılık sistemi dışında kalan kısmen veya tamamen kredi aracılığı yapan unsurlar ve faaliyetler" şeklinde tanımlanan gölge bankalar da küresel finans krizini tetikleyen önemli bir unsur olmaktadır (Gür, 2015: 10).

Tablo 1: Mali istikrarı tehdit edebilecek risk unsurları

\begin{tabular}{|c|l|}
\hline Kurumsal Bazlı Riskler & Piyasa Bazlı Riskler \\
a-Finansal Riskler & a-Diğer Kurumların Risk Altında Olması \\
Kredi & b-Varlık Fiyatlarındaki Oynaklıklar \\
Piyasa & c-Kredi ve Likiditede Yaşanan Sıkışıklıklar \\
Likidite & d-Bulaşıcılık Etkisi \\
Faiz & \\
\hline
\end{tabular}




\begin{tabular}{|c|c|}
\hline $\begin{array}{l}\text { Döviz } \\
\text { b- Operasyonel Riskler } \\
\text { c- Bilgi Teknolojileri Zayıflıkları } \\
\text { d- Yasal Yapıdan Kaynaklanan Riskler } \\
\text { e- Yolsuzluk } \\
\text { f- Stratejilerin Yanlış Belirlenmesi } \\
\text { g- Sermaye Yetersizliği } \\
\text { Dışsal Faktörler } \\
\text { a-Makro Ekonomik Görünümün Bozulması } \\
\text { b-Ekonomi Politikaları Etkinsizliği } \\
\text { c-Doğal Afet } \\
\text { d-Politik Sorunlar }\end{array}$ & $\begin{array}{l}\text { Altyapıdan Kaynaklanan Riskler } \\
\text { a-Takas İşlemleri ve Ödeme Sistemlerinden } \\
\text { Kaynaklanan Riskler } \\
\text { b-Yapısal Eksiklikler } \\
\text { Yasal Düzenlemelerin Yetersiz Olması } \\
\text { Denetim ve Gözetimin Yetersiz Olması } \\
\text { Muhasebe Standartları Etkinsizliği } \\
\text { c-Domino Etkisi }\end{array}$ \\
\hline
\end{tabular}

Darıcı (2012) tarafından oluşturulan yukarıdaki tabloda mali istikrarı tehdit edebilecek risk unsurları gösterilmiştir. Dolayısıyla bu riskler kurumsal bazlı, piyasa bazlı, dışsal veya ekonomik sistemin altyapısındaki yetersizliklerden kaynaklanabilmektedir. Mali sistemin istikrarlı olması için; mali kurum ve piyasaların, bir dış destek ya da müdahale olmaksızın sürekli çalışacakları ve sözleşmeye bağlı yükümlülüklerini yerine getireceklerine ilişkin güven olması yanında temel piyasaların da istikrarlı olması gerekmektedir. Küresel mali istikrarın gönüllü katılım ile sağlanabileceğinin en önemli savunucularından biri ABD Merkez Bankasının uzun süre başkanlığını yapmış olan Alan Greenspan'dır. Onun savunduğu görüşe göre, iktisadi karar birimleri öncelikle de bankalar, mali istikrarın önemini kavramış oldukları için bunu sağlayacak önlemleri kendi kendilerine alacaklardı. Bu nedenle de mali sisteme devletin müdahale etmesi hem gereksiz, hem de yanlış olurdu. Çünkü Greenspan devletin bilgi eksikliğinden dolayı daha yüksek maliyetli önlem alabileceğini, üstelik bu önlemlerin mali istikrara katkısının da az olabileceğini savunmaktaydı (Ersel, 2010: 18). Ancak 2007'de ABD'de başlayan krizle bu görüş etkisini önemli ölçüde yitirmiş oldu. Çünkü dünya 2007 son çeyreğinde başlayan ve ABD subprime (yüksek 
riskli) konut kredilerinden kaynaklanan ve özellikle Avrupa (başta İngiltere), Kanada ve Japonya'daki finansal piyasa ve kurumlara yansıyan bir ekonomik bunalım ve istikrarsızlık yaşamıştır (Batırel, 2008: 2). Kriz, 2003 yılından bu yana olan iyileşmenin tersine dönmesine, G-20 ülkelerinin mali dengelerinde bozulmaya ve gelişen ekonomilerin ekonomik büyümeye katkısının daha da düşmesine neden olmuştur. Gelişmiş ülkelerde mali dengedeki bozulmanın yarısı mali teşvik paketleri ve finansal sektörün desteklenmesinden ileri gelmektedir. Gelişen ekonomilerde ise, bozulma görece olarak mal ve varlık fiyatlarındaki düşüşten kaynaklanmaktadır (Karakurt, 2011: 39).

\subsection{Küresel Finansal İstikrarın Sağlanmasında Ulusal ve Uluslararası Kurumların Rolü}

Küresel finansal istikrarın sağlanması ulusal finansal istikrarların sağlanmasına bağlı olduğundan burada kamusal anlamda para ve maliye politikalarıyla desteklenen müdahalelere ihtiyaç duyulmaktadır. Para politikasının uygulanmasında ülkelerin merkez bankalarına büyük sorumluluklar yüklenmektedir. Çünkü içinde bulunduğumuz olağanüstü küresel konjonktür, merkez bankalarını, alışılagelmiş yaklaşımların dışına çıkarak alternatif politikalar tasarlamaya yöneltmektedir. Nitekim 2008 küresel finans krizinden sonra TCMB de düşük politika faiz oranı, yüksek zorunlu karş1lıklar ve geniş bir faiz koridorundan oluşan politika bileşiminin uygun bir strateji olduğuna işaret etmektedir. Böyle bir stratejinin her ülke için uygun olmasını beklemek yanlış olur. Dolayısıyla uygulanan politikalar ülkeye ve döneme göre tasarlanmakta, her ülke ve dönem için geçerli bir formül bulunmamaktadır (Başçı \& Kara, 2011: 19). Her ne kadar ekonomik istikrarın sağlanmasında para politikasının etkin olduğu görüşü yaygın olsa da, hükümetler gelir, harcama ve borçlanma gibi maliye politikalarıyla da finansal istikrarı desteklemeye çalışmaktadır. Bu konuda Sargent ve Wallece (1981) para ve maliye politikaları arasındaki etkileşimde hangi politikanın daha fazla yönlendirici olduğuna yönelik olarak, para politikasının önce- 
likli önemine değinmekle birlikte maliye politikası uygulanması sürecinde para politikası kararlarının göz önünde bulundurulmasının, makroekonomik koordinasyona katkı sağlayacağını vurgulamışlardır. Leeper (1991), Sims (1994) ve Woodford $(1994,1996,2001)$ vd. tarafından ortaya atılan Fiyatın Mali Teorisi'ne göre ise maliye politikasının enflasyonist sonuçlarını ortadan kaldırmak için merkez bankası bağımsızlığı yeterli olmamakta, merkez bankasının fiyat istikrarını sağlama hedefinin ancak maliye politikasının da dikkate alınmasıyla gerçekleştirilebileceği öne sürülmektedir (Özyılmaz, 2016: 30).

Ulusal piyasa başarısızlıklarının kaynağı olan finansal kurumların istikrarsızlı̆̆ı, negatif dışsallıklar ve bilgi eksikliği faktörlerinden bilgi eksikliğinin giderilmesi ve asimetrik bilgi sorununun çözülmesi için devletin düzenleyici ve denetleyici olarak rol alması gerekir. Bu anlamda hisse senedi ihracinda standart muhasebe ilkelerine uyulmasına, firmaların aktifleri ve kazançlarının kamuoyu ile paylaşılmasına, gerçek bilgilerini saklayanlara yönelik dolandırıcılık uygulamalarına ağır cezalar verdiren yasaların çıkarılmasına yönelik düzenlemeler yapılabilir. Bunların dışında sermaye hareketlerinin kamu otoritesi tarafından izlenmesi amacıyla döviz işlemleri üzerinden alınan ve döviz işlemlerindeki spekülatif akımları azaltan tobin vergisi alınabilir. Tobin'e göre mali krizlerin temelinde yatan en önemli nedenler yüksek hacimli döviz spekülasyonu ve dövizde yapılan günlük alım-satım işlemlerinin dünyadaki tüm borsalarda oluşan işlem hacminden daha fazla olmasıdır (Öcal \& Atay Polat, 2012: 75).

Küresel anlamda IMF, Dünya Bankası, BIS (The Bank of International Settlements), Basel Bankacılık Gözetim ve Denetim Otoritesi gibi kuruluşlar mali istikrarın sağlanmasına yönelik kurulmuşlardır. Avrupa Birliği çapında ise ESM (Avrupa İstikrar Mekanizmas1), EBA (Avrupa Bankacılık Otoritesi), EIOPA (Avrupa Sigorta ve Emeklilik Otoritesi) ve ESMA (Avrupa Menkul Kıymetler ve Piyasalar Otoritesi) kurulmuştur. Bilindiği gibi IMF’nin temel yükümlülüğü uluslararası mali istikrarı sağlamaktır. IMF, gözetim, teknik yardım ve kredi verme işlevleri sayesinde ülkelerin akılcı ve uygun politikaları uygulamalarına yardımcı olmaktadır. IMF'ye katılan 
her ülke ekonomik ve mali politikalarını uluslararası topluluğun incelemesine açma yükümlülügünü kabul etmiş demektir. Yerel politikaların yerel istikrar ve ödemeler dengesi istikrarı üzerinde oluşturduğu riskleri inceleyerek ve gerekli düzenlemeleri tavsiye ederek, yerel politikaların ülkenin kendi istikrarını sağlayıp sağlamadığını değerlendirir. Ayrıca ülkelerin kriz esnasındaki kırılganlıklarını değerlendirmeye yönelik sistematik çalışma yapmak, Dünya Bankası ile işbirliği içerisinde ülkelerin mali sektörlerini değerlendirerek riskler ve kırılganlıklarla ilgili politik çözümlemeler geliştirilmesine yardımcı olmaktadır. Veri boşluklarının doldurulması, ülkelere teknik yardımların yapılması, büyüme ve güveni sağlamaya yardımcı olacak politika programlarını destekleyici finansal yardımları yapmak gibi fonksiyonları vardır. IMF ile birlikte Bretton Woods sisteminin önemli bir parçası olarak 1944'te kurulan Dünya Bankası ise kalkınmakta olan ülkelerin ekonomik ve sosyal gelişimlerini sağlayabilmeleri adına önemli bir kalkınma yardımı kaynağıdır. Ana misyonu küresel yoksulluğun azaltılması ve yaşam şartlarının iyileştirilmesi olan Dünya Bankası'nın bünyesinde Uluslararası İmar ve Kalkınma Bankası (IBRD), Uluslararası Finans Kurumu (IFC), Uluslararası Kalkınma Birliği (IDA), Çok Taraflı Yatırım Garanti Ajansı (MIGA) ve Uluslararası Yatırım Anlaşmazlıkları Çözüm Merkezi (ICSID) şeklinde beş farklı kurum bulunmaktadır. Bu kurumlar kaynak ve hesapları bakımından birbirinden bağımsız olmakla birlikte, üyelik, amaçlar ve yönetim ilişkileri açısından Dünya Bankası şemsiyesi altında toplanmışlardır (Öztürk, 2006: 38).

BIS, “Uluslararası Takas Bankası” 17 Mayıs 1930 yılında İsviçre'nin Basel şehrinde kurulmuş olup dünyanın en eski uluslararası finansal kurumudur ve uluslararası merkez bankası işbirliği için başlıca merkezdir. BIS bir danışma organıdır ve esas olarak Merkez bankaları için bir işbirliği formu oluşturma çabalarının yanı sıra, uluslararası piyasalarda istikrarı sağlamaya yönelik araştırmalar yapmak ve öneriler getirmek gibi görevleri de vardır. BIS' in bünyesinde kurulan Basel Bankacılık Gözetim ve Denetim Otoritesi ise İsviçre'nin Basel kentinde, uluslararası bankacılık alanında ortak düzenlemelere gitmek, uluslararası bankacılık sisteminde güvenliği sağlamak, bankaların genel olarak denetlenebilmelerine imkan verecek teknikleri 
geliştirmek, ulusal denetim otoritelerine yol göstermek gibi amaçlarla oluşturulmuştur. Komite, finansal piyasaların istikrarı artırmak, farklı ülkeler arasında bankacılık denetimi alanında eşitsizlikleri kaldırmak için çalışmalarda bulunmaya devam etmektedir. Düzenlemeleri tavsiye niteliği taşısa da bunlara uymayan ülkelerin bankacılık sistemleri, uluslararası platformda dışlanmakta, risk primleri de olumsuz yönde etkilenmektedir.

Avrupa çapında finansal istikrarın sağlanması adına kurulan Avrupa İstikrar Mekanizması(ESM) Avro alanı için öngörülmüş, daimi bir kriz çözüm mekanizmasıdır. Borç sorunu yaşayan ya da yaşama riski bulunan Avro Alanı ülkelerine mali destek sağlamak amacıyla oluşturulmuştur. Avro Alanı ülkelerinin 2 Şubat 2012 tarihinde imzaladığı hükümetler arası antlaşma ile kurulan Avrupa İstikrar Mekanizması, 8 Ekim 2012 tarihinde faaliyete geçmiştir. Daha önce aynı amaçla kurulan ve işleyen Avrupa Finansal İstikrar Mekanizması'nın yerini almıştır. Avrupa İstikrar Mekanizması, finansman faaliyetlerini para piyasası araçlarının yanı sıra 30 yıla kadar orta ve uzun vadeli borçlanma araçları ihraç ederek yerine getirmektedir. AB denetim otoriteleri ise EBA, EIOPA ve ESMA'dır. Merkezi Londra'da bulunan EBA 1 Ocak 2011 yılında faaliyete başlamıştır. EBA (Avrupa Bankacılık Otoritesi), finansal sistemin istikrarının temini, bankacılık piyasasının ve ürünlerin şeffaflığının sağlanması ve yatırımcıların korunması gibi konularda faaliyet göstermektedir. EIOPA (Avrupa Sigorta ve Emeklilik Otoritesi) 1094/2010 sayılı Parlamento ve Konsey Tüzüğü ile kurulmuş olup, Almanya’nın Frankfurt kentinde faaliyet göstermektedir. EIOPA'nın temel sorumlulukları arasında, finansal sistemde istikrarın sağlanmasına destek olunması, piyasa ve finansal ürünlerin şeffaflığının sağlanması, sigorta ile emeklilik sigortası sektöründeki tarafların korunması ve sigortacılık müktesebatı doğrultusunda yapılacak ulusal uygulamaların Birlik düzeyinde uyumlaştırılması bulunmaktadır. ESMA (Avrupa Menkul Kiymetler ve Piyasalar Otoritesi) ise 1095/2010 sayılı Parlamento ve Konsey Tüzüğü ile kurulmuş bağımsız bir AB kurumu olarak Fransa'nın başkenti Paris’te faaliyetlerine başlamıştır. Otoritenin amacı 
$\mathrm{AB}$ düzeyinde şeffaf, etkin ve fonksiyonel bir menkul kıymetler piyasasının oluşturulmasıdır. Bunu yaparken yatırımcı hakları ile beraber, finansal sistemin istikrarının da korunması hedeflenmektedir.

Mali istismarla mücadele, finansal istikrarın sağlanmasında önemli bir boyuttur. Kara para aklama, yetersiz banka denetimi ve yolsuzluk gibi kötüye kullanımlar, uluslararası finansal sisteme karşı açık tehdit oluşturmaktadır ve bunun küresel düzeyde ele alınması gerekir. IMF ve OECD gibi kurumlar bu konularla başa çıkmada açık bir karşılaştırmalı avantaja sahipken, ulusal bankalar finansal sektörü güçlendirme ve ülke düzeyinde yönetişimi iyileştirme çabalarına yardımcı olabilir ve mali kurumların ve işlemlerin şeffaflı̆̆ını ve denetimini güçlendirebilir. $\mathrm{Bu}$, birçok ülkede devam eden ve daha da araştırılması gereken bir konudur (World Bank, 2000: 4).

\section{Sonuç}

Bu çalışmada küreselleşmenin ve kamusal malların genel özelliklerinden yola çıkılarak finansal istikrarın da bir küresel kamusal mal olduğuna dikkat çekilmiştir. Finansal istikrardan çok istikrarsızlık ülkeler için önemli bir sorun teşkil etmektedir. Bu sorunun ortadan kaldırılması ya da hafifletilmesi ve uluslararası anlamda bir tehdit oluşturmaması için IMF, Dünya Bankası, BIS ve Basel Bankacılık Gözetim ve Denetim Otoritesi gibi bazı uluslararası kuruluşlar bulunmaktadır. Bu kuruluşların faaliyetleri üye ülkelerin mali yapılarının iyileştirilmesini ve bunun sürdürülmesini sağlayarak küresel ölçekte dünya ekonomileri için de istikrarsızlık oluşturabilecek etkenleri ortadan kaldırmaktadır.

Öyle ki bir ülkede yaşanan istikrarsızlığın etkileri diğer ülkelere kolayca sıçrayıp mali dengesizliklere yol açtığı için küresel istikrarın sağlanması ancak her bir ülkenin kendi mali durumunu disipline etmesine bağlıdır. Özellikle gelişmekte olan ülkelerin oluşturduğu risk gelişmiş ülkelere göre daha fazladır. IMF'nin Nisan 2017 Küresel Finansal İstikrar Raporu'nda da belirtildiği gibi, hükümetlerin ülke içindeki finansal şartları yönetmesi küresel finansal entegrasyonla daha da zorlaştırmaktadır. 
Yine bu raporda ülkelerin yerel finansal şartlarındaki değişimlerin "yüzde 20 ila 40"nı küresel finansal koşulların belirlediği ve özellikle yükselen piyasa ekonomilerinin parasal şoklara karşı tedbirli olması gerektiğine vurgu yapılmıştır.

Küresel finansal istikrarın sağlanması her ne kadar küresel işbirliği gerektirse de devletlerin de ulusal anlamda kamusal ve piyasa faaliyetlerinde düzenleyici ve denetleyici olarak; mali saydamlığın sağlanması, mali disiplin, finansal kurumların istikrarsızlığı, negatif dışsallıklar ve bilgi eksikliği gibi sorunlarda aktif rol alması gerekir.

\section{Sonnotlar}

1. https://www.thebalance.com/gatt-purpose-history-pros-cons-3305578, 9 Mayıs 2017.

2. http://www.mfa.gov.tr/dunya-ticaret-orgutu-_dto_.tr.mfa, 9 May1s 2017.

3. https://www.imf.org/external/country/tur/rr/2012/022712f.pdf, 12 Mayıs 2017.

4. web.hitit.edu.tr/dosyalar/materyaller/oemrekoc@ hititedutr171220147U4F6P7R.docx, 8 May1s 2017.

5. http://www.ikv.org.tr/ikv_kriz_sozlugu/html/files/assets/common/downloads/publication.pdf, 20 Ekim 2017.

6. https://www.ab.gov.tr/files/EMPB/avrupa_birligi_nde_yeni_denetleyici_otoriterler.pdf, 22 Ekim 2017.

\section{Kaynakça}

Akdemir, Ali, Şahin, Mehmet. (2006). Küresel kamusal malların üretim ve yönetim dinamikleri bağlamında sınıflandırılması. Maliye Dergisi, 150, 1-24.

Akdoğan, Abdurrahman. (2006). Kamu maliyesi. (11. Bask1), Ankara: Gazi Kitabevi.

Allen, William A., Wood, Geoffrey. (2006). Defining and achieving financial stability. Journal of Financial Stability, 2 (2), 152-172.

Bandt, Olivier, Hartmann, Philipp. (2000). Systemic risk: A Survey. European Central Bank Working Paper Series, No: 35, November.

Baş̧̧1, Erdem, Kara, Hakan. (2011). Finansal istikrar ve para politikası. Türkiye Cumhuriyeti Merkez Bankası Çalışma Tebliği, No:11/08, Mayıs. 
Batırel, Ömer Faruk. (2008). Global ekonomik kriz ve türk kamu maliyesi. İstanbul Ticaret Üniversitesi Sosyal Bilimler Dergisi, 7 (13), 1-9.

Bayar, Fırat. (2008). Küreselleşme kavramı ve küreselleşme sürecinde türkiye. Uluslararası Ekonomik Sorunlar Dergisi, 33, 25-34.

Bernanke, Ben S. (1983). Nonmonetary effects of the financial crisis in the propagation of the great depression. The American Economic Review, 73 (3), 257-276.

Borio Claudio, Drehmann, Mathias. (2009). Towards an operational framework for financial stability: "Fuzzy" measurement and 1ts consequences. BIS Working Papers, No 284, June.

Bossone, Biagio, Promisel, Larry. (1998). Strengthening financial systems in developing countries: The case for incentives-based financial sector reforms. responding to the global financial crisis, The World Bank. http://documents.worldbank.org/curated/en/484681468155968806/pdf/718490WP00PUBL070092B0strengthening.pdf. Erişim tarihi: 03.11.2017

Crockett, Andrew D. (1997). Why is financial stability a goal of public policy. Economic Policy Symposium -Jackson Hole, 7-36.

Darıc1, Burak. (2012). Finansal İstikrar ve Finansal İstikrara Yönelik Kamusal Sorumluluk Çerçevesinde Para Politikası: Türkiye Analizi. Bankacılar Dergisi, 83, 34-66.

Das, Dilip K. (2010). Globalisation: Past and present. Institute of Economic Affairs, March, $30(1), 66-70$.

Ersel, Hasan. (2010). Bir küresel kamusal mal olarak mali istikrar ve g20. İktisat ve Toplum Dergisi, 1(2), 16-24.

Fisher, Irving. (1933). The Debt-deflation theory of great depressions. Econometrica, 1, 337357.

Gür, Nurullah. (2015). G20 ve küresel finans yönetişimi. SETA, 129, 7-24.

Issing, Otmar. (2003). Monetary and financial stability: is there a trade-off?. in: paper delivered to conference on 'monetary stability, financial stability and the business cycle', Bank for International Settlements, Basel, March 28-29.

Karakurt, Birol. (2011). Washington konsensüsü’nden küresel mali krize mali disiplin ve türkiye'deki gelişmeler. Atatürk Üniversitesi İktisadi ve İdari Bilimler Dergisi, 25 (1), 31-53. 
Kaul, Inge, Grunberg Isabelle, Stern, Marc A. (1999). Definıng Global Publıc Goods. Oxford University Press.

Korkmaz, Özge, Yamak, Rahmi. (2015). Minsky finansal istikrarsızlık hipotezi ve Türkiye örneği. Anadolu Üniversitesi Sosyal Bilimler Dergisi, 15 (3), 51-70.

Leeper, Eric M. (1991). Equilibria under 'active' and 'passive' monetary and fiscal policies. Journal of Monetary Economics, 27 (1), 129-147.

Minsky, Hyman P. (1982). Debt deflation process in today's institutional environment. Banca Nazionale Del Lavoro, 143, 375-393.

Mishkin, Frederic S. (1991). Asymmetric 1nformation and financial crises: A historical perspective. National Bureau of Economic Research, January, 69-108.

Mishkin, Frederic S. (1992). Anatomy of financial crisis. NBER Working Paper, No: 3934, $2(2), 115-130$.

Mishkin, Frederic S. (1997). The Causes and propagation of financial instability: lessons for policymakers. Economic Policy Symposium -Jackson Hole, 55-96.

Morrissey, Oliver, Velde, Dirk Willem, Hewitt, Adrian. (2002). Defining 1nternational public goods: Conceptual issues. Overseas Development Institute, London, January.

Öcal, Fatih Mehmet, Atay Polat, Melike. (2012). Küresel düzeyde sermaye hareketlerini yönetmede tobin vergisi: Türkiye örneği. Erciyes Üniversitesi İktisadi ve İdari Bilimler Fakültesi Dergisi, 40, 67-94.

Öztürk, İlhan. (2006). Dünya bankası politikaları. Sosyal Bilimler Dergisi, 3 (1), MPRA No.335.

Özyılmaz, Ayfer. (2016). Para ve maliye politikaları arasındaki koordinasyonun makroekonomik değişkenler üzerindeki etkinliği. Balkan ve Yakın Doğu Sosyal Bilimler Dergisi, 02 (01), 28-34.

Sargent, Thomas J., Wallace, Neil. (1981). Some Unpleasant Monetristarithmetic, Federal Bank of Minneapolis Quarterly Review, 5 (3), 1-17.

Schinasi, Garry J. (2004). Defining Financial Stability. IMF Working Paper, WP/04/187, October.

Sims, Christopher A. (1994). A Simple model for study of the determination of the price level and the interaction of monetary and fiscal policy. Economic Theory, 4, 381-399.

Şen, Ali ve Altay, Hüseyin. (2009). Finansal istikrarsızlık hipotezi bağlamında global finansal kriz. Eskişehir Üniversitesi Sosyal Bilimler Dergisi, 10 (1), 163-179. 
Uğurlu, Aytaç. (2010). Kamusal mallarda bedavacılık sorunu. Yüksek lisans tezi, Trabzon: Karadeniz Teknik Üniversitesi Sosyal Bilimler Enstitüsü.

Ulusoy, Ahmet, Karakurt, Birol, Ela, Mehmet. (2015). Borç deflasyonu: Teorinin gelişimi ve avrupa'da borç deflasyonuna ilişskin değerlendirmeler. Uluslararası Yönetim İktisat ve Işletme Dergisi, 11 (26), 1-28.

Yalçın, Arman Zafer. (2009). Küresel çevre politikalarının küresel kamusal mallar perspektifinden değerlendirilmesi. Balıkesir Üniversitesi Sosyal Bilimler Enstitüsü Dergisi, 12 (21), 288-309.

Yay, Turan, Gürkan Yay, Gülsün, Yılmaz, Ensar (Haz.). (2001). Küreselleşme sürecinde finansal krizler ve finansal düzenlemeler. (1. Basım). İstanbul: İstanbul Ticaret Odası.

Woodford, Michael. (1994). Monetary policy and price level determinacy in a cash-in-advance economy. Economic Theory, 4 (3), 345-380.

Woodford, Michael. (1996). Control of the public debt: A requirement for price stability? NBER Working Paper, No.5684, 1-39.

Woodford, Michael. (2001). Fiscal requirements for price stability. NBER Working Paper, No. 8072, 1-79.

World Bank Development Committee. (2000). Poverty reduction and global public goods: Issues forth he world bank in supporting global collective action. World Bank Staff Paper, DC/2000-16, September, Washington. 